\title{
Community Service: Processing Data Statistically
}

\author{
Diah Oga Nusantari ${ }^{1 *}$, Deni Nasir Ahmad ${ }^{1}$, Ihwan Zulkarnain ${ }^{1}$ \\ ${ }^{1}$ Mathematics Education, Universitas Indraprasta PGRI \\ Pasar Rebo, East Jakarta 13760 \\ Jakarta, Indonesia \\ diah.nusantari@unindra.ac.id
}

\begin{abstract}
Statistics is a part of mathematics that discusses data processing. An institution needs statistics to process and manage data so that information can be conveyed clearly. Technological developments make calculations easier with applications. This article describes the utilization of statistics for institutions with Excel applications. The result in community services, information can be conveyed to the public clearly and effectively.
\end{abstract}

Keywords: statistics, processing data, excel

\section{Introduction}

Much attention has been given to service-learning as a powerful program that interacts with students and the community in learning [1]-[3]. Students learned quite a lot from service-learning [4]. Categorization of mathematics into two parts namely school and practical mathematics. Practical Mathematics is a human activity involving mathematics in everyday life. However, most people consider it difficult while they practice mathematics. School mathematics is formal mathematics taught at School includes geometry, algebra, statistics.

Statistics is one part of the material in the mathematics curriculum. Students are expected to have skills in processing data by utilizing statistics so that they can explain a situation. Descriptive statistics relate to data collection, data presentation, and data analysis to obtain descriptions, clarity, or measurement of objects [5], [6]. Data processing results are then presented in a graphic or attractive image as a communicative way to explain any phenomenon to the wider community based on real data. Data or facts submitted through statistics should be informative, communicative, useful, and practical statistics are subjects related to (1) data collection correctly to optimize the information obtained, (2) to process, to be summarized, and to present data, (3) to analyze data so that we can devise specific strategies to face the situation, (4) how to conclude a situation and suggest decision making, and (5) To determine the probability of an error from a suitable decision for the data strategy [7], [8].

Statistical data processing can be done by (a) manually, meaning processing data using a formula without a computer program. More time is required to perform the process, (b) computerized, meaning processing data using computer programs such as SPSS, Amos, Excel, etc. The user only inputs the data then the computer program will process the data. The presence of ease of access technology should be utilized to assist in the data processing. At least using computerization is the effectiveness. However, technological sophistication has not been followed by mastery of skills in use so it is still found lack of the use of technology in the data processing.

In the service-learning, students partnered with the institution of Jatiwarna, Pondok Melati District, in Bekasi City. The team assists in utilizing statistics for data processing with Excel applications. Application project management solutions in service-learning typically easy-to-learn, easy-to-use [9]. The Excel Program contains some simple data analysis that can be mastered easily. Presenting information with tables and graphs provides an understanding of information easily. Institutions such as government offices usually put up posters or banners containing information about the community in public space. 


\section{Method}

The method used in the community service is processing data, simplified presented, then communicate data processing result about any information from partners data to 3rd party. As a partner, we engage Kelurahan Jatiwarna, Kecamatan Pondok Melati, Bekasi City. Service learning system apply trough process: students make design for community service, analysis situation trough interview, document review, develop application, build the applications and deliver the solutions [9].

The following are the steps taken before and during the community service activity: a. community service team were visiting partners to identify the needs of partners, b. direct observation to identify partner's data, this step was doing before community service program and during activity. The benefit of direct observation is to identify the problem and also to know the partner's resources that can be utilized on the program, d. doing processing data statistically, studying, and analyze the results of processing data, e. evaluate the community service activity followed by interactive discussion among participants both from the community service team and partners. Community service team its selves consist of three lecturers and ten students from mathematics education majors Universitas Indraprasta PGRI Jakarta. To communicate the result of processing data to the public, the team provides posters displays of pictures and graphs.

\section{Result}

The community service program held in October 2018 to January 2019. This program aims to engage students from education mathematics major to apply their skill which acquired in the campus to the local community. From basic statistics subject, students taught to counting data statistically, processing, and provide the result so that the public can clearly understand community phenomena based on data. Product as a result of the community service program is a report of descriptive data explanation about people's growth, number or birth, number of productive age, and economic growth rate and also posters of graph and diagram picture. The following are steps that have been done on community service program in Kelurahan Jatiwarna, as students learning experiences to apply their skill in processing data and explain the result to local community: First, team request permit to organize community service program in partner's office;
Identifying data and studying data to determine the right processing procedure for data Students and lectures discussing about processing data procedure which also as student training in applying their processing data statistically ability which acquired in campus

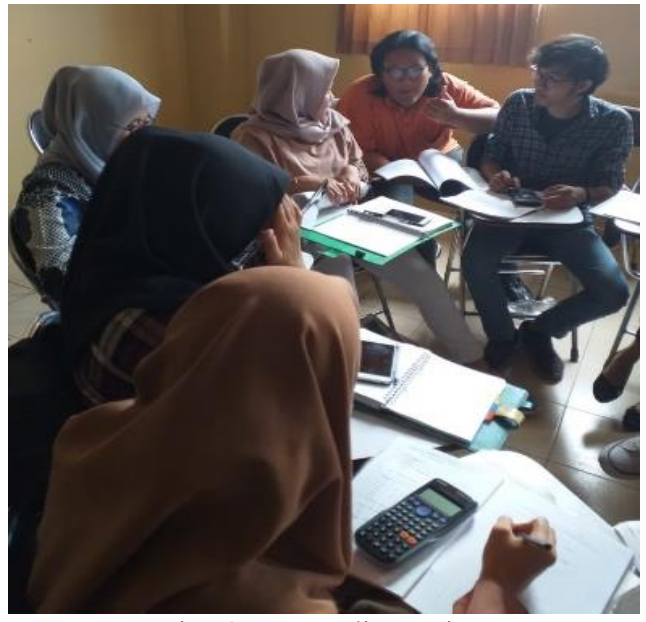

Fig. 1. Team discussion

After processing data, community service team represented by lecturer submit the processing result to partner which represented by the head of demographics and statistics affairs. Our product programs are reports and posters. Below is one of our poster

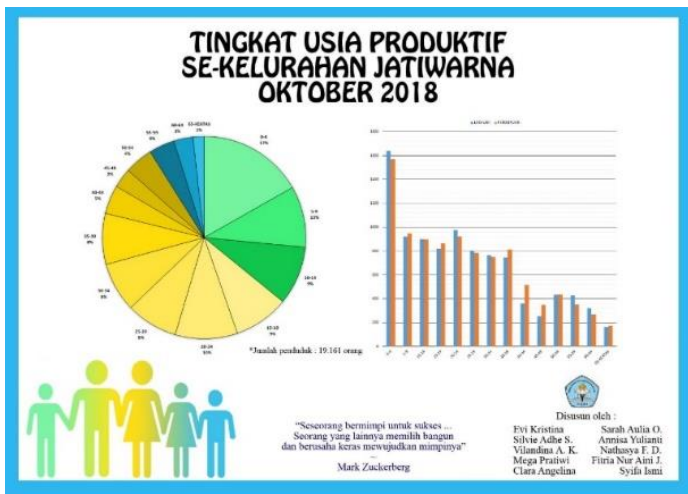

Fig. 2. Product of community service program

In the classroom most of the students already skeptical thinking to basic statistics subjects, especially in the data processing chapter, but when students facing real data students are even excited to study. Student creates a simple program in excel to processing data instead 


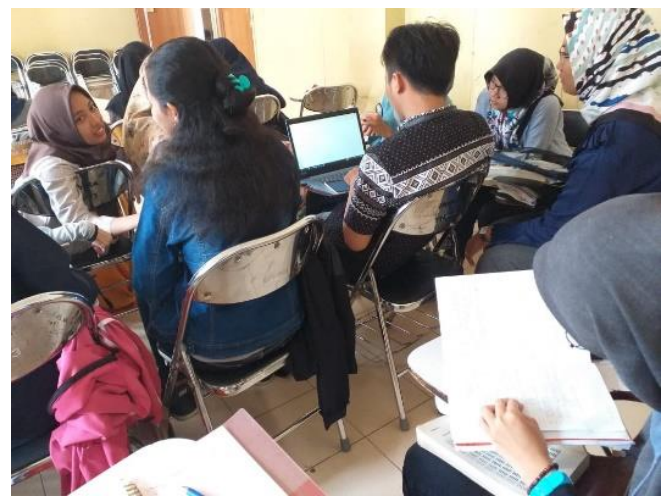

Fig. 3. Lectures assist the student to create a program on excel

During the community service program, some inputs are given to our team, partner requires cooperation in processing data statistically, continuing in several periods to ensure recency and also for accuracy data information. Data processing collaboration also needed to facilitate partners in data reporting to a higher level. For example, report leading up to the general election, society welfare, etc.

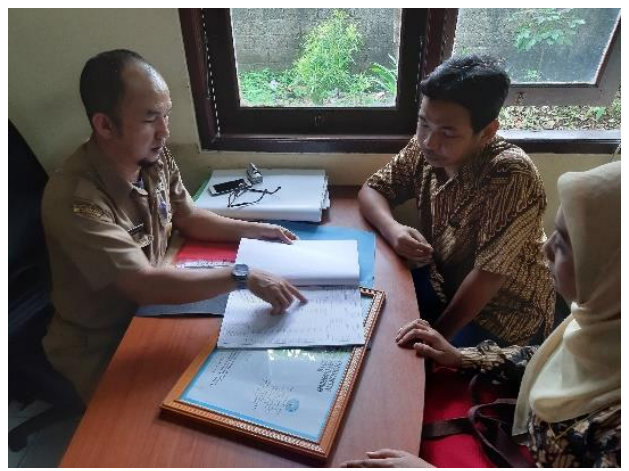

Fig. 4. Sharing and discussion team and partner

The processing data program on community service important for the partner in collecting accurate information from real data. The clear and accurate information base on data will avoid any suspicion.

\section{Discussion}

Community service activities organized by mathematics education have a positive impact on students. Students actively collaborate well with colleagues. Cooperation determines the solution of a problem is a form of problem solving. In the future, students must have social sensitivity and have empathy to solve problems around them. This is in line with the OECD that the competencies that students need in the next ten years include cognitive and meta-cognitive skills (critical thinking, creative thinking, learning to learn and organize themselves); social and emotional skills (empathy, selfefficacy and collaboration); and practical and physical skills (using new information and communication technology devices) [10]. Collaboration with peers is competencies for sustainable development in $21 \mathrm{st}$ century [11] [12].

Communication is an important part of the success of community service programs. Students approach the government agencies. Of course this requires good communication skills. Through this program, students learn to practice communication and negotiation skills. The advantages of service learning activities can improve students' abilities: tolerance, leadership, communication, problem solver, sensitivity to policy [9].

Community service programs can improve students' beliefs about the role of mathematics. Statistics is a material that is widely used in community service [13][14]. Implementing this program can improve student statistical skills [15]. We can see the enthusiasm of students utilizing their skills for this program. This is in line with Jeniffer that by understanding the benefits and objectives of mathematics, students have attitudes and beliefs about mathematics and statistics [16]. Service learning program can develop students' attitudes both themselves, school, community [17] [18].

The challenge going forward is to ensure that sensitivity to providing community service services is not just a program that is organized because of demands from the university. The current weakness is the service activity due to demands from the university. Of course this is part of the evaluation that the ultimate goal of this program is the emergence of self-awareness without coercion and demands. Self-awareness to play a role in providing benefits to society. The main challenge is how to ensure that the mandatory service learning requirement is not just another hurdle for graduation but rather a truly transformative [19].

\section{Conclusion}

After community program we conclude, apparently, partner greatly helped in processing data statistically then manage the result by a report back to the wide community in simple appearance and easy to understand for various levels of public. Managing data of community must clear and accurate, especially in certain periods such as general election, the ambiguous and biased information will bring out suspicion to any interested party. Therefore the 
collaboration between our team and partner is very meaningful. After a community program, we can suggest that students must have a willingness to apply their ability from campus to a wide community not only in government institutions but also in another institution. Because student's ability truly needed in the community.

\section{References}

[1] S. H. Billig, 'Service-Learning', in The Encyclopedia of Child and Adolescent Development, Wiley, 2020, pp. 111.

[2] J. E. Anderson and E. A. Sungur, 'Community service statistics projects’, Am. Stat., vol. 53, no. 2, pp. 132-136, 1999.

[3] G. Ngai, S. C. F. Chan, and K. P. Kwan, 'Challenge, meaning, interest, and preparation: Critical success factors influencing student learning outcomes from service-learning', J. High. Educ. Outreach Engagem., vol. 22, no. 4, pp. 55-80, 2018.

[4] G. Ngai, C. H. Y. Lam, K. Kwan, and S. C. F. Chan, 'Instituting a Service-Learning Requirement in Higher Education: Evaluation and Lessons Learned', Springer, Singapore, 2019, pp. 323-341.

[5] M. E. Rendón-Macías, M. Á. Villasís-Keever, and M. G. Miranda-Novales, 'Descriptive statistics', Rev. Alerg. Mex., 2016.

[6] S. Pérez-Vicente and M. Expósito Ruiz, 'Descriptive statistics', Allergol. Immunopathol. (Madr)., 2009.

[7] D. Middleton and J. A. Rice, 'Mathematical Statistics and Data Analysis', Math. Gaz., 1988.

[8] H. L. Rietz, Mathematical statistics. 2013.

[9] J. Hoxmeier and M. M. Lenk, 'Service-Learning in Information Systems Courses: Community Projects that Make a Difference', J. Inf. Syst. Educ., vol. 14, no. 1, p. 91, 2003.

[10] OECD, PISA 2018 Results COMBINED EXECUTIVE SUMMARIES VOLUME I, II \& III, vol. I. SecretaryGeneral of the OECD, 2019.

[11] P. Xu and X. Yue, 'Talent leadership strategies enhance teacher's professional competencies in 21 st century education for sustainable development', IOP Conf. Ser. Earth Environ. Sci., vol. 373, no. 1, 2019.

[12] M. C. Zaragoza, J. Díaz-Gibson, A. F. Caparrós, and S. L. Solé, 'The teacher of the 21st century: professional competencies in Catalonia today', Educ. Stud., vol. 00, no. 00, pp. 1-21, 2019.

[13] B. King, J. Bartman, and I. Gil, 'The Problem-Based Threshold: Shifting Pre-Service Teachers' Thinking About Mathematics Instruction', Teach. Educ., vol. 55, no. 1, pp. 88-106, Jan. 2020.

[14] R. Root and T. Thorme, 'Community-based projects in applied statistics: Using service-learning to enhance student understanding', Am. Stat., vol. 55, no. 4, pp. 326$331,2001$.

[15] M. Wells, "Teaching notes: Making statistics "real" for social work students', J. Soc. Work Educ., vol. 42, no. 2, pp. 397-404, 2006.

[16] G. S. U. U. S. Leong Jennifer, 'High school students' attitudes and beliefs regarding statistics in a service- learning-based statistics course.', Diss. Abstr. Int. Sect. A Humanit. Soc. Sci., vol. 68, 2008.

[17] C. I. Celio, J. Durlak, and A. Dymnicki, 'A Meta-analysis of the Impact of Service-Learning on Students', vol. 34, no. 2, pp. 164-181, 2011.

[18] V. F. Mcgowan, 'An assessment of service learning objectives and outcomes', J. Transform. Learn., vol. 2, no. 4, pp. 43-55, 2017.

[19] S. C. F. Chan, G. Ngai, and K. P. Kwan, 'Mandatory service learning at university: Do less-inclined students learn from it?', Act. Learn. High. Educ., vol. 20, no. 3, pp. 189-202, 2019. 